\title{
Brief information module: The examination of psychology and medical students knowledge and attitudes toward Electro-Convulsive Therapy (ECT)
}

\author{
Kısa bilgi modülü: Psikoloji ve Tıp bölümü öğrencilerinin Elektro-Konvulsif \\ Terapiye (EKT) ilişkin bilgi ve tutumlarının incelenmesi \\ Samet Çelik¹, Nuray Atasoy², Seydahmet Ercan³, Mustafa Oğuz ${ }^{4}$ \\ 1 Psych., Zonguldak Bulent Ecevit University, Health Practice and Research Center, Zonguldak, Turkey \\ https://orcid.org/0000-0002-0578-3126 \\ 2Prof., 4 M.D., Zonguldak Bulent Ecevit University, Medicine Faculty, Department of Psychiatry, Zonguldak, Turkey \\ https://orcid.org/0000-0003-0514-5906-https://orcid.org/0000-0002-2160-3965 \\ ${ }^{3}$ Assis. Prof., Zonguldak Bulent Ecevit University, Faculty of Arts and Sciences, Department of Psychology, Zonguldak, Turkey \\ https://orcid.org/0000-0002-9174-9249
}

\section{SUMMARY}

Objective: The purpose of this study is to compare knowledge and attitude towards ECT. For this purpose, we compared first, second and fifth-grade students of medical faculty and students of psychology MSc with thesis. Method: In first part, 480 students participated in the pretest process. After that, 212 first and secondgrade students had a training named ECT information module. 2 weeks later, these 212 participants were subjected to a posttest of their knowledge and attitudes towards ECT. Results: The pre-test results showed that the knowledge level of the participants about the ECT increased compatibly with their grade level. Additionally, while ECT knowledge level of clinical psychology students was higher than that of medical students, their attitudes towards ECT were more negative. An ECT semistructured info module was presented to the experiment group. According to the results of ANOVA analysis, the level of knowledge about ECT increased equally among psychology and medical students. Discussion: Pretest results revealed that students in higher grades have higher knowledge levels. However, when the departments were compared by grade levels, psychology students are found to have a much higher knowledge level than medical students, yet they have more negative attitudes. This result shows that although ECT knowledge level rises, attitudes do not

always rise.

\section{ÖZET}

Amaç: Bu çalışmanın amacı tıp fakültesi ve psikoloji bölümü öğrencilerinin EKT'ye yönelik bilgi ve tutumlarını karşılaştırmaktır. Yöntem: Çalışmanın ilk bölümünde toplam 480 öğrenci katılmıştır. Daha sonra 212 birinci ve ikinci sınıf olan tıp fakültesi ve psikoloji bölümü öğrencilerine EKT'ye yönelik bilgi modülü anlatılmıştır. İki hafta sonra aynı öğrencilere EKT'ye yönelik bilgi ve tutumlarını değerlendirmek üzere ölçek uygulanmıştır. Bulgular: Ön test sonuçları EKT'ye yönelik bilgi düzeyinin sınıf düzeyi ile birlikte arttığını göstermektedir. Buna ek olarak, klinik psikoloji öğrencilerinin bilgi düzeyi tıp fakültesi öğrencilerinin bilgi düzeyine göre daha yüksek bulunmuştur; ancak klinik psikoloji öğrencilerinin tutumları daha olumsuzdur. EKT'ye yönelik eğitimin etkisi incelendiğinde, verilen eğitimin her iki bölüm öğrencilerinde de EKT'ye yönelik bilgi düzeyini artırdığı görülmüştür. Sonuç: Psikoloji bölümü öğrencilerinin tıp fakültesi öğrencilerine göre bilgi düzeylerinin yüksek olmasına rağmen, tutumlarının daha olumsuz olması şaşırtıcıdır. Bu durumun erken dönemde formal ya da informal kaynaklardan alınan bilginin yanlış ya da tutarsız olması ile ilişkili olabileceği düşünülmektedir; ancak verilen eğitimin katılımcıların hem bilgi hem de tutum düzeylerini olumlu yönde etkilediği bulunmuştur.

Anahtar Sözcükler: Tutum, EKT, bilgi, eğitim, psikolog

Key Words: Attitudes, ECT, knowledge, education, psychologist

(Turkish J Clinical Psychiatry 2021;24:77-85)

DOI: $10.5505 / \mathrm{kpd} .2020 .47135$ 


\section{INTRODUCTION}

Electro-convulsive therapy (ECT) is one of the effective treatment methods used in the treatment of psychiatric disorders (1). ECT is mainly used in the treatment of many neurological and mental disorders such as depression, schizophrenia, bipolar disorder, epilepsy and Parkinson's disease (2). In addition to these pathologies, it is a common treatment method among individuals who are at risk of suicide (3), pregnant patients who cannot or do not want to use any drug (4), patients who are unresponsive to drugs (5) and catatonic patients (6).

In the literature, some of the studies related to ECT are indications and efficacy studies of the treatment as mentioned above. Commonly analyzed/ discussed topics are ethical debates on ECT's methodology and efficacy (7-9).

Although there are many studies on the efficacy and safety of ECT, studies show that many participants have negative attitudes and misinformation $(10,11)$. Among these participants, the most important ones are doctors (12), nurses (13), psychologists (14) and the general population (15). For this purpose, students are frequently included in attitude researches about ECT to show that the negative attitudes are caused by both lack of information and misinformation $(16,17)$.

Some methods are frequently used to change negative attitudes and beliefs towards ECT $(1,18)$. However, many examples show that the lack of information is the main reason for negative attitudes and beliefs towards ECT (19).

In the national literature, the researches on ECT in Turkey focus on different clinical applications $(20,21)$. There are no studies in terms of attitudes and behaviors towards ECT except the study of Alpak et al. (2015) which was conducted with medical faculty assistants (22) with various sample groups on knowledge and attitudes.

This study aims to determine the knowledge and attitude levels of medical and psychology students. Although the studies in the literature suggest that the reason for negative attitudes is due to lack of information, these studies are interpreted mostly through descriptive statistics.

\section{METHOD}

\section{Sampling}

For the present study, the sample was collected by two different methods. The first sample group consists of first, second and fifth-grade medical students in Zonguldak Bülent Ecevit University, and the first and second-grade students studying at the psychology department of the same university (Since there is no 3rd or 4th year students in psychology department at the time of the research, only 1 st and 2 nd year students were involved.). In this sample group, the questionnaire was randomly distributed among the volunteers who accepted to participate in the study. To compare the knowledge and attitudes of the fifth-grade medical students, we included the students, who have completed the course period of clinical psychology MA with thesis in the universities of Turkey. Clinical psychology students were contacted by using snowball sampling method through Google forms. Students who had "A formal training on ECT" during the course period of a clinical psychology MA program were included in the study. Similarly, the fifth-grade students of the medical faculty were given formal training on ECT during psychiatry training. Clinical psychology students and fifth-grade medical students were included in the study because they both received formal training on ECT during their education. That is why, they are considered equal.

A total of 480 people participated in the study. Of all the participants, $70.6 \%$ of them were women. The mean age of all participants was $20.87 \pm 2.47$. According to the data of medical faculty students' departments and grades, $17.71 \%(\mathrm{n}=85)$ of them were first-year students, $10.63 \%$ were second-year students, and $10.83 \%$ were fifth-year students. A total of 188 volunteers participated from medicine faculty in the study. A total of 292 students participated in the study from the psychology department, $21.66 \%(n=104)$ of them were first-year students, $29.38 \%(\mathrm{n}=141)$ were second-year students and $9.80 \%(n=47)$ were clinical psychology students. 


\section{Materials}

Pre- and post-training scale materials were developed by a specialist psychologist, a psychiatric assistant, a social psychologist and a specialist psychiatrist. In addition to the demographic information of the participant, such as gender, department, and age, the scale contains questions that are used to measure the experience and knowledge of the participant of ECT (e.g., Do you know someone who received ECT treatment?). Besides, specialist psychologist and psychiatric assistant prepared a 43item questionnaire about knowledge and attitude to examine the participants' current knowledge and attitudes about ECT. The attitude researches of ECT in the literature and the questions the researches received from the patients throughout their clinical history formed the scale materials after their modification as a questionnaire.

Finally, the Knowledge and Attitude Questionnaire on ECT was completed and later it was reduced down to 37 questions after the revisions by social psychologist and psychiatrist regarding the content and language characteristics of the items. As a result of validity and reliability analyzes in the final test, the questionnaire was reduced down to 25 items. The entire scale is designed to be filled in approximately 5-10 minutes.

\section{Procedure}

First of all, we evaluated the current knowledge and attitudes of all participants with a pretest. Two weeks after the pretest, the participants were trained and the final test was conducted two weeks after the training. Therefore, the experimental part of the study lasted 30- 45 days. Pretest, training, and posttest were conducted every other two weeks because if the posttest is applied immediately after the training, this can lead the participants to respond through social desirability. Thus, their answers may not reflect their actual knowledge and they might only answer what they were told in the last test. Therefore, the desired information was whether the participants internalized the training and changed their attitudes or not.

The ECT training program was designed and developed by specialist psychiatrist. The average training period took $70-80$ minutes in a single session. Sixty minutes of the training content is theoretical education, 7 minutes is about video demonstration about ECT and an average of 10 minutes was spared to the students' questions. In the theoretical part of the training, the discussed topics were; the history of ECT, printed media presentations of ECT, indications, side effects, the ECT patients, contraindications, how to perform, the methods used during ECT procedure and the physiological and biochemical effects of ECT. The content of the video consisted of the real-practice ECT demonstrations, prejudices and negative attitudes of the general population towards psychiatric disorders.

The study was conducted with the approval of the Ethics Committee of Human Research at Zonguldak Bülent Ecevit University (Approval date: 29.12.2017; Approval number: 283) .

\section{RESULTS}

Reliability and Validity Analyses of Knowledge and Attitude Scale of ECT

The first reliability and validity analyses of the questionnaire were conducted with 480 participants obtained from the pretest and the reliability was calculated again with the final test of 212 participants.

The ECT questionnaire included 37 questions, 21 of them were knowledge items and 16 were attitude items. We conducted factor analysis separately from knowledge items and attitude items. Because, the knowledge items were coded as binary $(1=$ true; $0=$ false). The tetrachoric correlation matrix is recommended to perform a factor analysis of binary-coded items (23-25). Five-point Likert scale finds out the attitude items so the Pearson correlation was performed in the factor analysis of the attitude items.

Firstly, factor analysis was performed using the pretest data set for 21 knowledge items of the ECT questionnaire. We used Factor software for this 
analysis, developed by LorenzoSeva and Ferrando (26) to apply factor analysis of binary items. We chose this program because it uses a tetrachoric correlation matrix to perform factor analysis. At the end of the first analysis, we observed that the loading of 5 out of 21 items were low and we performed a second analysis after excluding these items. The results of the second analysis indicated a two-factor result for the knowledge items. Goodness of fit statistics also confirmed the twofactor result (Comparative Fit Index $(\mathrm{CFI})=0.98$; Adjusted Goodness of Fit Index (AGFI) = 0.96; The Root Mean Square Error of Approximation (RMSEA) <.05). In addition, Schwarz's Bayesian Information Criterion

Dimensionality Test also indicated that the two-factor produced the most appropriate results. We performed the factor analysis again using the posttest data set for 16 items obtained from the pretest data set. The results obtained from the last test data set supported the results obtained from the pretest data set. However, 3 of the remaining 16 items did not load on any of the two test data sets. After excluding these three items, the 2-factor knowledge scale with 13 items was finalized. Reliability analysis was conducted for knowledge items with 13 questions. According to the results of the reliability analysis, the internal consistency reliability coefficient of the pretest and the last test data sets were 0.61 and 0.72 , respectively. The internal consistency reliability coefficient of the pretest and posttest data for factor 2 were 0.58 and 0.60 , respectively. As the Cronbach Alpha scores are biased downward in two-choice items (27), we can state that our coefficient results are within acceptable reliability range. The first factor of the knowledge items is labelled "Knowledge about Effects and Side Effects (KESE)" and includes knowledge items on the effects and side effects of ECT (as in "ECT is a form of treatment that kills brain cells; ECT is a treatment method with life-threatening and critical adverse effects"). The second factor is labelled "Knowledge about Indications (KAI)" (as in "ECT is a method of punishing guilty and maladjusted patients; ECT is used to treat homosexuals.").

Secondly, we conducted a factor analysis with the pretest data set for 16 attitude items of the pretest data. We used a parallel analysis code developed by
O'Connor (2000) for the SPSS program to identify the number of the factors of the attitude scale (28). The parallel analysis considers the calculated eigenvalue results that can be observed by chance. Parallel analysis found that two of the calculated eigenvalues are too big to observe. This result indicated that the attitude scale had two factors. Thus, we applied a two-factor analysis using the pretest data set. At the end of the analysis, we observed that one item was not loaded on any of the factors. We performed a two-factor analysis again with the last test data set of the remaining 15 items. We used the Promax rotation in these factor analyses. The results from the last test data set confirmed the results of the pretest data set. Furthermore, 2 of the remaining 15 items were not loaded on one of the two factors in the last test data set and one item was loaded on both factors at a similar level. After excluding these 3 items, we finalized the two-factor attitude scale with 12 items. We applied the reliability analyses with the items determined in factor analysis. As a result, the internal consistency reliability coefficients of factor 1 for the pretest and posttest data sets were 0.82 and 0.65 , respectively. The internal consistency coefficient of factor 2 for the pretest and posttest data sets were 0.88 and 0.90 , respectively. We labelled first factor as "Trust on Treatment (TT)". This factor measures the participants' confidence level about ECT (e.g., "I would not accept ECT treatment even if my physician recommends it; I would accept receiving ECT if I had severe depression"). The second factor named "Attitudes Towards Receiving and Performing ECT (AtRP)" (e.g., "If one of my friends receives ECT treatment, I would completely stop seeing him; I do not want to become friends with someone who received ECT").

\section{Examination of Pretest Results of Knowledge and Attitudes towards ECT}

We examined the knowledge and attitude level differences among participants towards ECT according to their departments and grade levels with the two-way ANOVA. At this point, we examined the sub-factors of knowledge and attitude separately.

After the examination of the effects of grades and departments on KESE scores of participants with 
two-way ANOVA, a significant difference was found between the participant's department and KESE scores $(\mathrm{F}(1-462)=8.37 ; \mathrm{p}=0.00)$. There is a significant difference among KESE sub-factor scores according to departments and grades (F (2$462)=3.05 ; p=0.04)$. Partial Eta-Squared values show that the major effect is at the grade level.

As mentioned above, the department has a major effect on KESE scores. There is a significant difference among KESE sub-factor scores according to the grade levels. Accordingly, the mean scores of psychology department students $(0.17 \pm 0.20)$ are higher than the mean scores of medical school students $(0.12 \pm 0.17)$. The effect of the grade levels on KESE scores was also examined. According to this, no difference was found between the KESE scores of the first $(0.11 \pm 0.15)$ and second $(0.15 \pm 0.18)$ grades. Whereas, the KESE mean score of the fifth grades $(0.24 \pm 0.23)$ was found statistically significantly higher than the scores of first and second grades.

A significant difference was found between the department and the KAI sub-factor as a result of the two-way ANOVA (F (1-475) $=20.95 ; \mathrm{p}=0.00)$. Indication levels of individuals also differ according to grade levels. $(\mathrm{F}(2-475)=7.58 ; \mathrm{p}=0.00)$. There is a significant difference among KAI sub-factor scores regarding grades $(p>0.05)$. The major effect was on grade level according to the Partial EtaSquared values.

The grade levels have a major effect on KAI points. Accordingly, the KAI sub-factor mean scores of the fifth grades (regardless of the departments) $(0.71 \pm 0.28)$ are significantly higher than the scores of the first $(0.55 \pm 0.28)$ and second $(0,55 \pm 0.28)$ grades.

We also examined the attitude sub-factors and the grade-department variance effect. First of all, we conducted a two-way ANOVA for the TT sub-factor. According to this, there is no significant difference in TT scores regarding grade variance $(p>0.05)$. However, there is a significant difference regarding department variance $(\mathrm{F}(1-472)=9.11$; $\mathrm{p}=0.00)$. Thus, grades and departments have a common effect on TT $(\mathrm{F}(2-472)=3.10 ; \mathrm{p}=0.04)$.

\section{The major effect is on the department level accor- ding to Partial Eta-Squared values.}

The mean scores of medical students are higher than the scores of psychology students when compared according to the TT sub-factor scores among departments (regardless of grade levels). The TT mean scores of the first-grade medical students $(3.08 \pm 0.39)$ are statistically higher than the TT mean scores of the first-grade psychology students $(3.02 \pm 0.55)$. The scores of the second-grade medical students $(3.08 \pm 0.39)$ are statistically higher than the scores of the second-grade psychology students $(3,12 \pm 0.54)$. And, the scores of fifth-grade medical students $(3.34 \pm 0.51)$ are statistically higher than the students of clinical psychology MA with thesis $(2.98 \pm 0.89)$.

Lastly, we compared the mean scores regarding sub-factors of the Attitudes Towards Receiving and Performing ECT (AtRP). AtRP scores show a significant difference according to the grade variance due to two-way ANOVA regarding the AtRP subfactor $(\mathrm{F}(2-476)=3.43 ; \mathrm{p}=0.03)$. AtRP shows a significant difference regarding department variance $(\mathrm{F}(1-476)=4.16 ; \mathrm{p}=0.04)$. Thus, the grades and departments have a common effect on TT (F $(2-476)=4.77 ; p=0.00)$. The Partial Eta-Squared values showed that the most effect was in both grade and department.

The department is reported to have a main effect on the AtRP sub-factor. The AtRP subfactor scores of psychology students $(4.16 \pm 0.58)$ are higher than the scores of medical faculty students $(3.99 \pm 0.59)$.

\section{Repeated Measurements of Variance Analysis Results}

In this part, we examined before and after the training scores of the ECT Knowledge and Attitude Questionnaire. Two hundred twelve students participated in this part of the study. Fortyseven percent of them were first and second-grade medical students. The rest consists of first and second-grade psychology students. In the pretest, no significant difference was found in any of the subfactors between first and second grades regarding knowledge and attitude variances. For this reason, 
Celik S, Atasoy N, Ercan S, Oguz M.

Table 1. Comparison of mean and standard deviation scores regarding sub-factors ofthe groups.

\begin{tabular}{|c|c|c|c|c|c|c|}
\hline \multirow{2}{*}{\multicolumn{2}{|c|}{ Sub-factors }} & \multicolumn{2}{|l|}{ Medical Faculty } & \multicolumn{3}{|l|}{ Psychology Department } \\
\hline & & Training Group $(n=59)$ & Control Group $(n=39)$ & Training Group $(\mathrm{n}=57)$ & Control Group $(n=53)$ & $\mathrm{p}$ \\
\hline \multirow{3}{*}{$\begin{array}{l}\sqrt[1]{2} \\
\sqrt[1]{1} \\
\frac{1}{1}\end{array}$} & Pretest & $0.13-0.21$ & $0.9-0.14$ & $0.18-0.20$ & $0.18-0.19$ & $0.000^{*}$ \\
\hline & Posttest & $0.60-0.29$ & $0.14-0.16$ & $0.44-0.27$ & $0.28-0.18$ & \\
\hline & Pretest & $0.52-0.24$ & $0.43-0.28$ & $0.58-0.27$ & $0.68-0.27$ & $0.063^{*}$ \\
\hline \multirow{2}{*}{$\underset{\Downarrow}{\mathbb{\Sigma}}$} & Posttest & $0.75-0.20$ & $0.48-0.25$ & $0.66-0.30$ & $0.69-0.32$ & \\
\hline & Pretest & $3.34-0.44$ & $3.08-0.36$ & $3.09-0.51$ & $3.07-0.58$ & $0.001^{*}$ \\
\hline \multirow{3}{*}{ 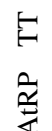 } & Posttest & $3.88-0.64$ & $3.23-0.36$ & $3.54-0.70$ & $3.28-0.61$ & \\
\hline & Pretest & $4.14-0.58$ & $3.77-0.57$ & $4.12-0.53$ & $4.21-0.46$ & $0.000^{*}$ \\
\hline & Posttest & $4.49-0.56$ & $3.67-0.66$ & $4.19-1.05$ & $4.08-0.77$ & \\
\hline
\end{tabular}

the students were distributed to control and training groups regardless of the grades. Out of all the participants $(\mathrm{N}=212), 56.44 \%$ of them volunteered for the "ECT Information Module" and the remaining was determined as the control group.

We analyzed participant's pretest and posttest data with repeated measurement variance analysis. The analysis was repeated separately for every factor. Thus, the training has a significant effect (with a variance of 20\%) on the KESE scores. $(\mathrm{F}(1-198)=$ 51.886; $\mathrm{p}<0.05)$. The common interaction between the department and the training reported a significant common effect on the change in KESE scores $(\mathrm{F}(1-198)=13.99 ; \mathrm{p}<0.00)$.

As a result of the repeated measurement variance analysis, the training has a significant effect on KAI sub-factor scores. (F $(1-204)=16.40 ; p<0.00)$. The variance of the training on the KAI sub-scale scores was $7 \%$. Similarly, the department has a significant effect on KAI scores. $(\mathrm{F}(1-204)=12.69 ; \mathrm{p}<0.00)$. The common interaction between the department and the training was found to have no significant common effect on the change in KAI scores $(\mathrm{p}>0.05)$.

As a result of the repeated measurement variance analysis, the training has a significant effect on TT sub-factor scores $(\mathrm{F}(1-205)=20.03 ; \mathrm{p}<0.00)$. The variance of the education on the TT scores was $9 \%$. Similarly, the department also has a significant effect on TT scores. $(\mathrm{F}(1-205)=5.42 ; \mathrm{p}<0.05)$. The common interaction between the department and the training was found to have a significant common effect on the change in TT scores (F (1$205)=2.34 ; \mathrm{p}<0.05)$. As a result of the repeated measurement variance analysis, the training has a significant effect on AtRP sub-factor scores (F (1$207)=14.82 ; \mathrm{p}<0.00)$. The variance of the training on AtRP scores was 7\%. The department has no significant effect on AtRP scores $(p>0.05)$. The interaction between the department and the training was found to have no significant common effect on the change in AtRP scores $(\mathrm{F}(1-207)=14.48$; $\mathrm{p}<.05)$. See Table 1 for pretest and posttest mean scores.

\section{DISCUSSION}

In the present study, we aimed to evaluate the ECT knowledge and attitude levels of medical and psychology students. We also investigated the effect of semi-structured training on knowledge and attitudes of students. On the other hand, we aimed to increase the participant diversity by including MA students who completed clinical psychology course period and fifthgrade medical students in the pretest part. We aimed to detect the relationship between grade levels and knowledge and attitudes. Lastly, although theoretical training may seem like the most commonly used method to change the attitudes in the literature $(19,29,30)$, there is no statistical way of examining the extent of the effect of knowledge on attitude. This is because no causality can be set between knowledge and attitude due to the non-standardization of the research scales. However, descriptive statistics comes forefront when it comes to previous researches $(13,17)$. One of the most genuine points of this research is that it developed a validity and reliability scale to reveal the effect of the knowledge level of ECT on attitudes towards ECT. 
Firstly, we compared KESE pretest scores of both psychology and medical students. According to this comparison, there is no significant difference between the first and second grades while there is a difference among first and second grades, and fifthgrade students. KESE scores of both medical and clinical psychology students are statistically significantly higher than the scores of the first and second-grade students. In this sense, an accordingly increasing knowledge which increases with the grade level is an expected result. When KESE scores are compared regarding departments and grades, psychology students seem more knowledgeable about ECT than medical students. In the firstgrades, the scores of sub-factors are close, however, when the grade level gets higher, the KESE score differences widen between psychology and medical students.

KAI sub-factor results are similar. Knowledge levels of psychology students (regardless of grades) regarding ECT indications are higher than medical student's levels. When it comes to grades, the higher the grade levels are, the higher the scores get.

In general, psychology student's knowledge levels are higher than the medical student's knowledge, this could be associated with their specialization. In other words, psychology students have a lot more courses on clinical psychology than medical students. Formal education is the reason for the score differences.

Attitudes become more positive with the increase knowledge of literature $(17,30)$, however, we come up with the results incompatible with the literature for the TT sub-factor. In particular, clinical psychology students have twice as much efficiency, side-effect and indication knowledge of ECT than fifth-grade medical students. Yet, their attitudes are more negative.

The second attitude sub-factor results are similar. Attitudes of clinical psychology students towards people who perform and receive ECT, are more negative than that of fifthgrade students.

There is no study in the literature on why knowledge levels of psychologists do not make a positive change on their attitudes, yet there are some speculations over it. At the beginning of the study, the number of clinical psychology students was 51, but 4 of them were excluded from the study because they claimed that they never had any courses on ECT during their university years, they obtained their knowledge of ECT through their own efforts. It is remarkable that a treatment method, which has been effectively used for a long time for the treatment of psychologically and neurologically ill patients, is not included in the training curriculum of the clinical psychology MA program. This would give us a clue on the attitudes of psychology students towards ECT. Besides, the non-scientific use of ECT in the past might still have negative effects on the attitudes of psychologists. Among these non-scientific uses, we can include its previous use as a punishment of disobedience $(31,32)$, its use as a treatment of gay and lesbians (33) and its performance without any kind of sedation, all of which could be why the psychologists may develop a negative point of view towards ECT.

As mentioned above, patients and patients' relatives come first among the groups with negative attitudes towards ECT. Psychologists have an important role in preventing this. They stated that they did not agree with the item stating "If one of my patients is to have ECT treatment, I would encourage him." or they were hesitant to support this statement which was within the context of Trust to Treatment. When psychiatrists recommend ECT to patients, the patients and patient's relatives may consult psychologists to share their doubts about their treatments. From another point of view, sometimes psychologists may seem like they are against the treatment methods of psychiatrists. The main reason for this view is that psychologists cannot prescribe medication for treatment. When the patient consults with his psychologist, the psychologist's attitude on this matter may be crucial on the patient's decision about continuing the ECT treatment. Any kind of negative attitude towards ECT may lead to prevention or even cancellation of the patient's ECT treatment. This would extend the length of the patient's treatment period and may lead to ethical problems.

According to repeated measurement variance analysis, a semi-structured training module over ECT is 
shown to increase the knowledge level of ECT and affect the attitudes towards ECT positively. Our finding is consistent with other researches which investigate contributions of theoretical training in changing attitudes and knowledge level $(30,34)$. According to this finding, theoretical training on ECT is recommended during the formal education of both medical schools and psychology departments. However, patient-based programs are thought to be beneficial to change attitudes (35). Students' attitudes towards ECT are thought to change permanently when they get involved in the ECT process themselves and closely observe the patient's whole ECT treatment process.

In addition to the aforementioned strengths, the present study also has some limitations. Firstly, our participants consist of students residing in the Zonguldak province except for clinical psychology

\section{REFERENCES}

1. Balhara Y, Yadav T, Mathur S, Kataria D. The impact of a brief ECT orientation module on the knowledge and attitudes of medical students towards ECT in India. Annals of Medical and Health Sciences Research 2012; 2(2):140-145. doi:10.4103/2141-9248.105661

2. Baghai TC, Möller HJ. Electroconvulsive therapy and its different indications. Dialogues Clin Neurosci 2008; 10:105-117.

3. Prudic J, Sackeim HA. Electroconvulsive therapy and suicide risk. J Clin Psychiatry 1999; 60(2):104-110.

4. Leiknes K, Cooke M, Jarosch-von Schweder L, Harboe I, Høie B. Electroconvulsive therapy during pregnancy: A systematic review of case studies. Archives of Women's Mental Health 2013; 18(1):1-39. Doi: 10.1007/s00737-013-0389-0

5. Devanand DP, Sackeim HA, Prudic J. Electroconvulsive therapy in the treatment resistant patient. Psychiatr Clin North Am 1991; 14(4):905-923.

6. Carroll BT, Kirkhart R, Ahuja N, Soovere I, Lauterbach EC, Dhossche D, Talbert R. Katatonia: A new conceptual understanding of catatonia and a new rating scale. Psychiatry (Edgmont) 2008; 5(12):42-50.

7. Consoli A, Benmiloud M, Wachtel L, Dhossche D, Cohen D, Bonnot O. Electroconvulsive therapy in adolescents with the catatonia syndrome. The Journal of ECT 2010; 26(4):259-265. Doi: 10.1097/YCT.0b013e3181fb3924

8. Cohen D, Flament M, Taieb O, Thompson C, Basquin M. Electroconvulsive therapy in adolescence. European Child \& Adolescent Psychiatry 2000; 9(1):1-6. Doi:10.1007/s007870050109

9. Ottosson J, Fink M. Electroconvulsive therapy. New York: Brunner-Routledge; 2004.

10. Fink M. Convulsive therapy: A review of the first 55 years. J Affect Disord 2001; 63(1-3):1-15. Doi: 10.1016/s01650327(00)00367-0 students. Another limitation is that the reliability coefficient of the TT subfactor of the scale, which was developed for this study, is lower than the general acceptance level for the pretest. Thus, the present study is mainly a descriptive study that aims to provide useful insight for the upcoming studies. In particular, it is necessary to conduct qualitative and quantitative studies investigating the reasons for the students' negative attitudes.

Correspondence address: Psyhc., Samet Celik, Zonguldak Bulent Ecevit University, Health Practice And Research Center, Zonguldak, Turkey psk.sametcelik@gmail.com

11. Challiner V, Griffiths L. Electroconvulsive therapy: A review of the literatüre. J Psychiatr Ment Health Nurs 2007; 7(3):191198. Doi: 10.1046/j.1365- 2850.2000.00282.x

12. Byrne P, Cassidy B, Higgins P. Knowledge and attitudes toward electroconvulsive therapy among health care professionals and students. The Journal of ECT 2006; 22(2):133-138. Doi: 10.1097/00124509-200606000-00011

13. Gass J. The knowledge and attitudes of mental health nurses to electro-convulsive therapy. J Adv Nurs 1998; 27(1):83-90. Doi: $10.1046 / j .1365-2648.1998 .00507 . x$

14. Ghaziuddin N, Kaza M, Ghazi N, King C, Walter G, Rey J. Electroconvulsive therapy for minors: Experiences and attitudes of child psychiatrists and psychologists. The Journal of ECT 2001; 17(2):109-117.

15. Lauber C, Nordt C, Falcato L, Rössler W. Can a seizure help? The public's attitude toward electroconvulsive therapy. Psychiatry Research 2005; 134(2):205-209. Doi: 10.1016/j.psychres.2004.07.010

16. Andrade C, Kumar Rao NS. Medical students' attitudes toward electroconvulsive therapy: An Indian perspective. Convuls Ther 1996; 12(2):86-90.

17. Gazdag G, Kocsis-Ficzere N, Tolna J. Hungarian medical students' knowledge about and attitudes toward electroconvulsive therapy. The Journal of ECT 2005; 21(2):96-99. Doi: 10.1097/01.yct.0000165502.06410.d7

18. Gazdag G, Sebestyen G, Ungvari GS, Tolna J. Impact on psychiatric interns of watching live electroconvulsive treatment. Acad Psychiatry 2009; $3(2): 152-156$. Doi:10.1176/appi.ap.33.2.152

19. Oldewening K, Lange R, Willan S, Strangway C, Kang N, Iverson G. Effects of an education training program on attitudes to electroconvulsive therapy. The Journal of ECT 2007; 23(2):82-88. Doi: 10.1097/YCT.0b013e3180421a0a 
20. Tomruk NB, Oral T. Elektrokonvulsif tedavinin klinik kullanımı: Bir gözden geçirme. Anadolu Psikiyatri Derg 2007; 8:302-309.

21. Poyraz BC, Tosun M. Elektrokonvulzif terapide etkinlik mekanizması. Turkiye Klinikleri Psychiatry- Special Topics 2018; 11: 5-7.

22. Alpak G, Bülbül F, Ünal A, et al. Knowledge and attitudes of residents regarding electroconvulsive therapy. TAF Prev Med Bull 2015; 14:33-38

23. Lorenzo-Seva U, Ferrando PJ. TETRA-COM: a comprehensive SPSS program for estimating the tetrachoric correlation. Behavior Research Methods 2012; 44(4):1191- 1196. Doi: 10.3758/s13428-012-0200-6

24. Muthén B. Contributions to factor analysis of dichotomous variables. Psychometrika 1978; 43(4):551-560. Doi: 10.1007/bf02293813

25. Parry CD. McArdle JJ. An applied comparison of methods for least-squares factor analysis of dichotomous variables. Applied Psychological Measurement 1991; 15(1):35-46. Doi: 10.1177/014662169101500105

26. Lorenzo-Seva U, Ferrando PJ. FACTOR: A computer program to fit the exploratory factor analysis model. Behavior research methods 2006; 38(1):88-91. doi: 10.3758/bf03192753

27. Liu Y, Wu AD, Zumbo BD. The impact of outliers on Cronbach's coefficient alpha estimate of reliability: Ordinal/rating scale item responses. Educational and Psychological Measurement 2010; 70(1):5-21. Doi: $10.1177 \% 2$ F0013164409344548

28. O'connor BP. SPSS and SAS programs for determining the number of components using parallel analysis and Velicer's MAP test. Behavior Research Methods, Instruments, \& Computers 2000; 32(3):396-402. Doi: 10.3758/BF03200807

29. Andrews M, Hasking P. Effect of two educational interventions on knowledge and attitudes towards electroconvulsive therapy. The Journal of ECT 2004; 20(4):230-236. Doi: 10.1097/00124509-200412000-00008

30. Battersby M, Ben-Tovim D, Eden J. Electroconvulsive therapy: A study of attitudes and attitude change after seeing an educational video. Australian \& New Zealand Journal of Psychiatry 1993; 27(4):613-619. Doi: $10.3109 / 00048679309075824$

31. Wright BA. An historical review of electroconvulsive therapy. Jefferson Journal of Psychiatry 1990; 8(2):68-74. Doi: 10.29046/JJP.008.2.007

32. Lebensohn ZM. The history of electroconvulsive therapy in the United States and its place in American psychiatry: a personal memoir. Compr Psychiatry 1999; 40(3):173-181. Doi: 10.1016/s0010-440x(99)90000-7

33. Smith G, Bartlett A, King M. Treatments of homosexuality in Britain since the 1950san oral history: the experience of patients. BMJ 2004; 328(7437):427. Doi: 10.1136\%2Fbmj.37984.442419.EE

34. Walter G, McDonald A, Rey JM, Rosen A. Medical student knowledge and attitudes regarding ECT prior to and after viewing ECT scenes from movies. The Journal of ECT 2002; 18(1):43-46. Doi: 10.1097/00124509-200203000-00012
35. Paheenthararajah K, Ladas T, Gauggel S, Prinz S, Grözinger M. Medical students' attitudes towards electroconvulsive therapy: Impact of patient-oriented training. Der Nervenarzt 2015; 86(5):566-570. Doi: 10.1007/s00115-014-4093-8 